\title{
Characterization of protein marker expression, tumorigenicity, and doxorubicin chemoresistance in two new canine mammary tumor cell lines
}

Yen-Ling Hsiao' ${ }^{1}$, Tai-Zu Hsieh ${ }^{2,3}$, Chian-Jiun Liou ${ }^{4,5}$, Yeong-Hsiang Cheng ${ }^{1}$, Chung-Tien Linn ${ }^{2}$ Chi-Yao Chang ${ }^{3 *}$ and Yu-Shen Lai ${ }^{1 *}$

\begin{abstract}
Background: Canine mammary tumors (CMTs) are the most common type of cancer found in female dogs. Establishment and evaluation of tumor cell lines can facilitate investigations of the biological mechanisms of cancer. Different cell models are used to investigate genetic, epigenetic, and cellular pathways, cancer progression, and cancer therapeutics. Establishment of new cell models will greatly facilitate research in this field. In the present study, we established and characterized two new CMT cell lines derived from a single CMT.

Results: We established two cell lines from a single malignant CMT specimen: DTK-E and DTK-SME. Morphologically, the DTK-E cells were large, flat, and epithelial-like, whereas DTK-SME cells were round and epithelial-like. Doubling times were $24 \mathrm{~h}$ for DTK-E and $18 \mathrm{~h}$ for DTK-SME. On western blots, both cell lines expressed cytokeratin AE1, vimentin, cytokeratin 7 (CK7), and heat shock protein 27 (HSP27). Moreover, investigation of chemoresistance revealed that DTK-SME was more resistant to doxorubicin-induced apoptosis than DTK-E was. After xenotransplantation, both DTK-E and DTK-SME tumors appeared within 14 days, but the average size of DTK-SME tumors was greater than that of DTK-E tumors after 56 days.

Conclusion: We established two new cell lines from a single CMT, which exhibit significant diversity in cell morphology, protein marker expression, tumorigenicity, and chemoresistance. The results of this study revealed that the DTK-SME cell line was more resistant to doxorubicin-induced apoptosis and exhibited higher tumorigenicity in vivo than the DTK-E cell line. We anticipate that the two novel CMT cell lines established in this study will be useful for investigating the tumorigenesis of mammary carcinomas and for screening anticancer drugs.
\end{abstract}

Keywords: Canine mammary tumor, Cell line, Heat shock protein 27, Chemoresistance, Tumorigenicity

\section{Background}

Mammary gland carcinomas are the most common neoplasms in both women and female dogs [1,2]. Clinical evidence has shown that approximately $50 \%$ of canine mammary tumors (CMTs) are diagnosed as malignant in dogs [3]. CMTs possess epidemiological, clinicopathologi$\mathrm{cal}$, and biochemical characteristics similar to those of human breast carcinomas $[4,5]$. Therefore, CMTs have been considered an appropriate and valid model for human breast cancer studies for more than three decades [6].

\footnotetext{
* Correspondence: ychang@gate.sinica.edu.tw; yslai@niu.edu.tw

${ }^{3}$ Institute of Cellular and Organismic Biology, Academia Sinica, Taipei, Taiwan 'Department of Biotechnology and Animal Science, National Ilan University, Yilan, Taiwan

Full list of author information is available at the end of the article
}

Tumor cell lines have been widely used for in vitro research, and have proven to be a particularly useful tool for genetic analyses. Previous characterizations of tumor cell lines have shown that they are also excellent models for studying the biological mechanisms underlying cancer [7]. The use of tumor cell lines has increased our knowledge of the deregulated genes and signaling pathways involved in cancer $[8,9]$. Furthermore, original cell models have been developed to test anticancer drugs $[8,10-12]$. Tumor cell lines continue to be used in the development of new therapies $[7,11,13]$, and also provide an alternative to direct transplantation of tumors in animals for testing chemotherapeutics [14].

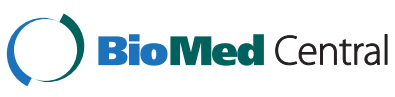

(C) 2014 Lai et al.; licensee BioMed Central Ltd. This is an Open Access article distributed under the terms of the Creative Commons Attribution License (http://creativecommons.org/licenses/by/4.0), which permits unrestricted use, distribution, and reproduction in any medium, provided the original work is properly credited. The Creative Commons Public Domain Dedication waiver (http://creativecommons.org/publicdomain/zero/1.0/) applies to the data made available in this article unless otherwise stated. 
The use of an appropriate in vitro model is crucial in cancer research. Different cell models are used to investigate genetic, epigenetic, and cellular pathways [7]; proliferation deregulation, apoptosis, and cancer progression [9]; and identification of potential molecular markers [15], as well as to screen and characterize cancer therapeutics $[11,16]$. The findings reported from tumor cell lines are typically extrapolated to in vivo human tumors [15]. Thus, many biomedical and pharmaceutical companies have recognized the importance of tumor cell lines as models for drug testing and translational studies [8].

In the present study, we established and characterized two new CMT cell lines, termed DTK-E and DTK-SME. These two cell lines exhibited significant diversity in cell morphology, protein marker expression, tumorigenicity, and chemoresistance. Our results suggest that the two established cell lines might constitute a useful experimental model for investigating the tumorigenesis of mammary carcinomas and for screening potential anticancer drugs.

\section{Results}

Morphological analysis of established cell lines

After over 100 passages, two CMT cell lines, DTK-E and DTK-SME, were established from canine mammary carcinomas. When adhered to a culture plate, DTK-E cells exhibited a large, flat, epithelial-like morphology (Figure 1A), while DTK-SME cells presented a rounded, epithelial-like morphology (Figure 1B). Of the two established cell lines, only DTK-SME cells possessed pile up (Figure 1B). Transmission electron micrographs showed that both DTK-E and DTK-SME cells exhibited high nuclear-cytoplasmic ratios and large nucleoli (Figure 2).

\section{Biological analysis of established cell lines}

Alterations in the biological properties of the two CMT cell lines were monitored during their establishment. During the first 10 passages, 50\% fetal bovine serum (FBS) was required to maintain cell growth. After 10 passages, the percentage of FBS in the medium was gradually reduced. After 100 passages, 5\% FBS was sufficient to support the growth of both CMT cell lines. In addition, contact inhibition was only significant during the first 35 passages, and was completely lost after 50 passages (data not shown). During establishment of the two CMT cell lines, we also determined the doubling time. The final doubling times for DTK-E and DTKSME cells were $24 \mathrm{~h}$ and $18 \mathrm{~h}$, respectively (Figure 3 ).

\section{Expression profile of CMT genes and proteins}

We used western blot analysis with specific antibodies to investigate the individual protein expression profiles of the two CMT cell lines (Table 1). Both CMT cell lines expressed the low-molecular weight cytokeratin AE1 and vimentin, cytokeratin 7 (CK7), and heat shock protein 27 (HSP27) (Figure 4A, B). In addition, DTK-SME exhibited a higher level of HSP27 expression than DTK-E cells. In reverse transcription-polymerase chain reaction (RT-PCR) assays, the $C K 7$ and $H S P 27$ gene expression profiles were the same as their respective protein expression profiles; both DTK-E and DTK-SME cells expressed CK7 and HSP27 genes (Figure 4C).

\section{Tumorigenicity of established CMT cell lines}

We performed xenografts to examine the tumorigenicity of the two CMT cell lines. At passage 100, each cell line was injected subcutaneously into five 8-week-old athymic mice (BALB/c nu/nu). A tumor mass was first observed at the injection site in all mice injected with DTK-E and DTK-SME cells at 1 week post-injection; at 8 weeks, the DTK-SME and DTK-E groups exhibited masses of $1.8-2.2 \mathrm{~cm}$ and $0.5-0.7 \mathrm{~cm}$ in diameter, respectively (Figure 5).

\section{Doxorubicin (DOX)-induced dose-dependent growth suppression, apoptosis, and caspase-3 activation in CMT cells}

Next, we investigated the susceptibility of the two CMT cell lines to DOX. Cells were treated with DOX and cell growth and apoptosis were analyzed at $24 \mathrm{~h}, 48 \mathrm{~h}$, and $72 \mathrm{~h}$. We found that DOX (1000 nM) was able to
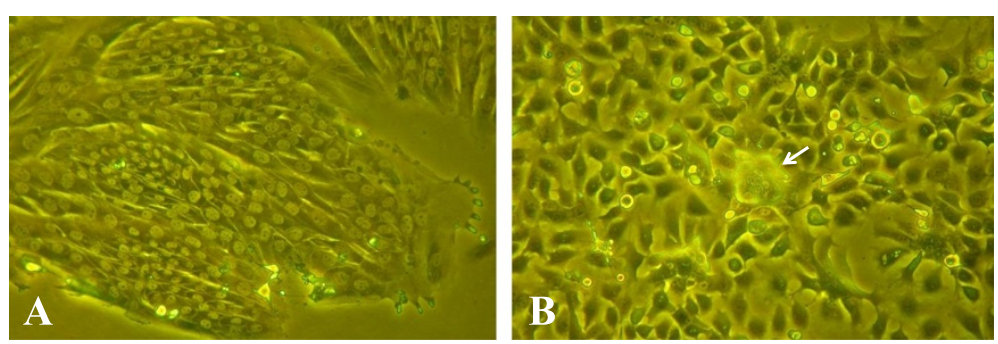

Figure 1 Phase contrast micrographs of CMT cells derived from malignant tumor tissue. (A) DTK-E cells displayed mostly large, flat epithelial-like characteristics; (B) DTK-SME cells displayed rounded, epithelial-like features and possessed pile up. Arrowhead indicates position of pile up. 


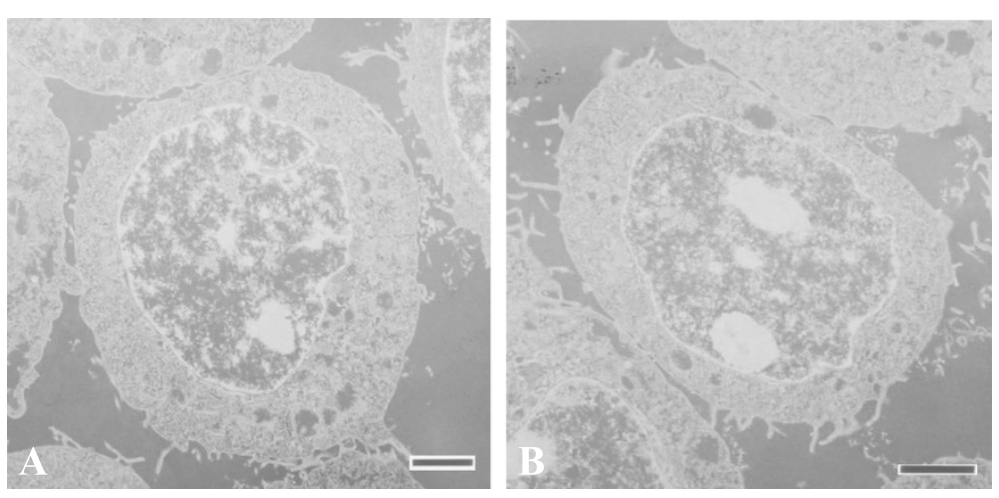

Figure 2 Transmission electron micrographs of CMT cell lines. Intracellular morphology of (A) DTK-E and (B) DTK-SME cells. Images are representative of 20 random sections per cell line. Scale bars $=2 \mu \mathrm{m}$.

promote apoptosis and inhibit proliferation in a doseand time-dependent manner in DTK-E cells, but not in DTK-SME cells (Figures 6 and 7). Further quantitative analysis revealed that 72-h exposures to $100 \mathrm{nM}$ and $1000 \mathrm{nM}$ DOX resulted in $2 \%$ and $58 \%$ mortality, respectively, in DTK-E cells (Figure 6). In addition, DOX $(1000 \mathrm{nM})$ treatment caused DNA fragmentation in DTK-E cells at $72 \mathrm{~h}$ (Figure 7A). In contrast, no DNA fragmentation was observed at $72 \mathrm{~h}$ in DTK-SME cells. Because activation of caspase- 3 is a hallmark of apoptosis, we examined caspase- 3 activation in DOXtreated (1000 nM) CMT cells (Figure 7B). DOX induced the time-dependent cleavage of procaspase-3 into its active caspase- 3 form in DTK-E cells, but not in DTK-SME cells.

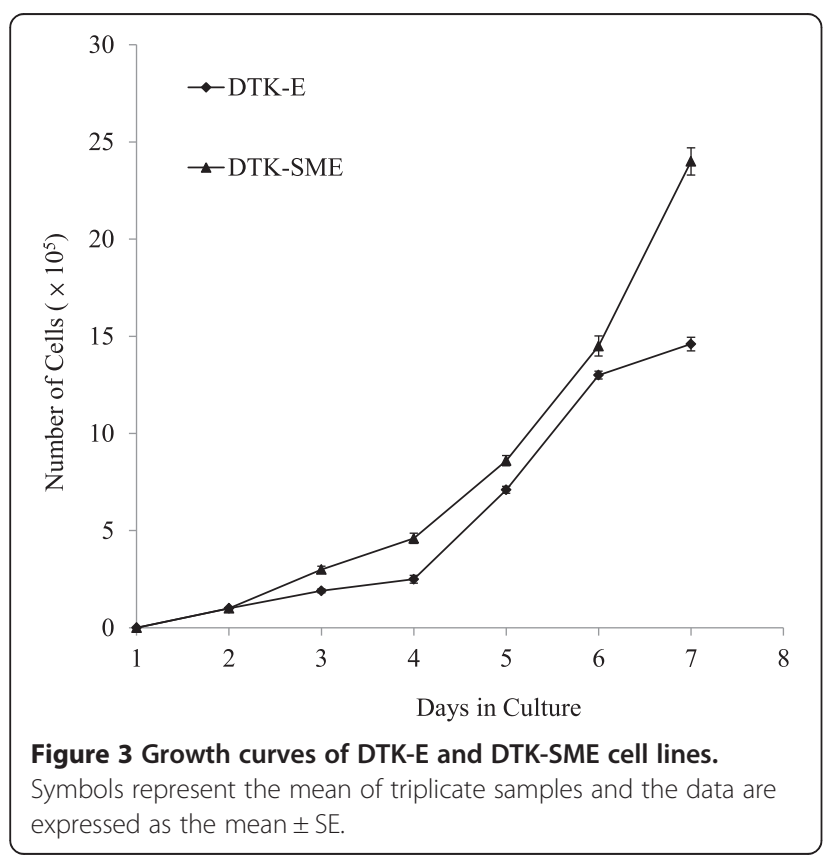

\section{Discussion}

In the present study, we established and characterized two new CMT cell lines derived from a single malignant tumor: DTK-E and DTK-SME. DTK-E cells showed a large, flat, epithelial-like morphology, while DTK-SME cells showed a rounded epithelial-like morphology. Both DTK-E and DTK-SME cells exhibited a high nuclear-cytoplasmic ratio, which is often associated with malignancy in tumor cells. Consistent with this finding, xenografts of injected DTK-E and DTK-SME cells developed into prominent solid tumors within 2 weeks, and the tumor mass of DTK-SME was larger than that of DTK-E after the 8-week study.

The human breast contains a branching ductal network composed of two epithelial cell types: an inner layer of polarized luminal epithelial cells and an outer layer of myoepithelial cells. Breast cancer arises mainly in the luminal epithelial compartment of the terminal duct lobular units $[17,18]$. Several proteins have been identified as important cell markers for investigating tumor pathophysiology. Cytokeratins (CKs) are critical markers of epithelial differentiation [19]. The distribution of CKs is tissue-specific, and this feature facilitates the determination of tumor origin [20-22]. One lowmolecular weight cytokeratin subtype, CK7, is a marker of luminal epithelial cells in both human and canine mammary tissues [23]. In a study of 435 cases, expression of

Table 1 Overview of the sources and dilutions of the primary antibodies used in this study

\begin{tabular}{llll}
\hline Antibody & Source & Clone & Dilution \\
\hline AE1 & NeoMarkers & AE1 (mouse monoclonal) & $1: 1000$ \\
Vimentin & NeoMarkers & V-9 (mouse monoclonal) & $1: 1000$ \\
CK 7 & Santa Cruz & 5F282 (mouse monoclonal) & $1: 1000$ \\
Hsp27 & GeneTex & GTX25579 (rabbit polyclonal) & $1: 1000$ \\
Caspase 3 & NeoMarkers & CPP (rabbit polyclonal) & $1: 1000$ \\
$\beta$-actin & Sigma & AC-15 (rabbit polyclonal) & $1: 5000$ \\
\hline
\end{tabular}


A

\section{DTK-E DTK-SME}

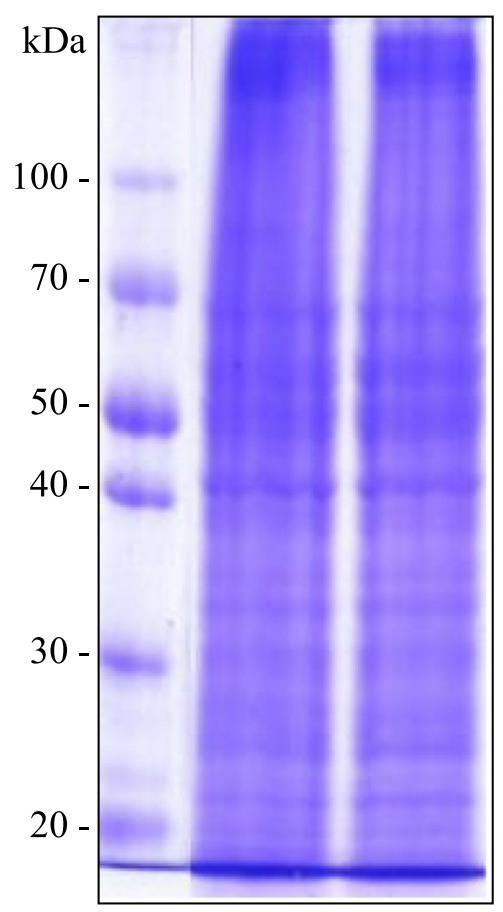

B

\section{DTK-E DTK-SME}

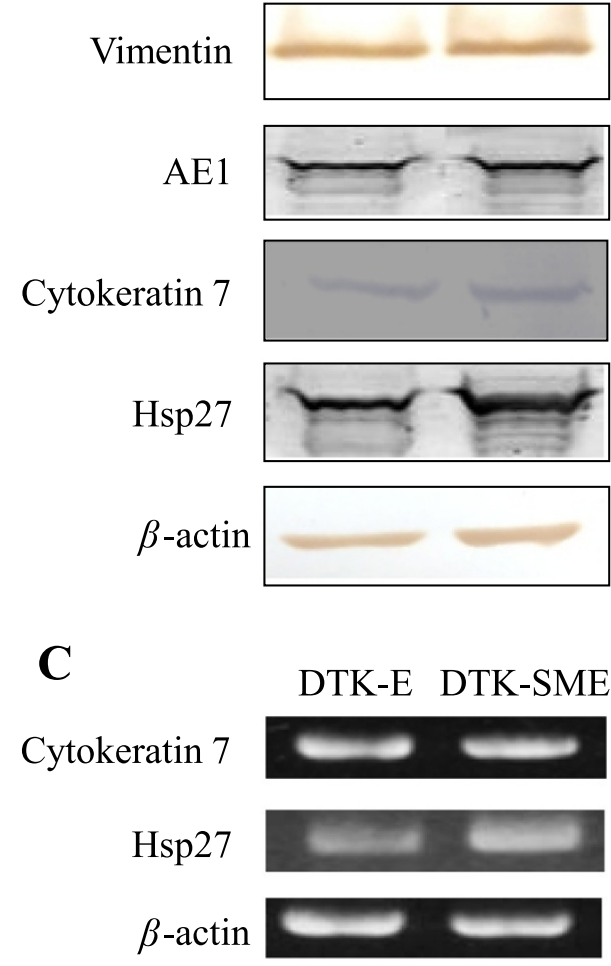

Figure 4 Expression profiles of protein markers in the DTK-E and DTK-SME cell lines. (A) Western blot analysis of total proteins in cell lysates. Lane 1, pre-stained protein marker; Lane 2, DTK-E; Lane 3, DTK-SME. (B) Protein expression in DTK-E and DTK-SME cell lines detected with antibodies to vimentin, cytokeratin 7 (CK7), low-molecular weight cytokeratin AE1, and heat shock protein 27 (HSP27). (C) RT-PCR analysis of CK7 and HSP27 gene expression in DTK-E and DTK-SME cell lines. $\beta$-actin served as an internal control.

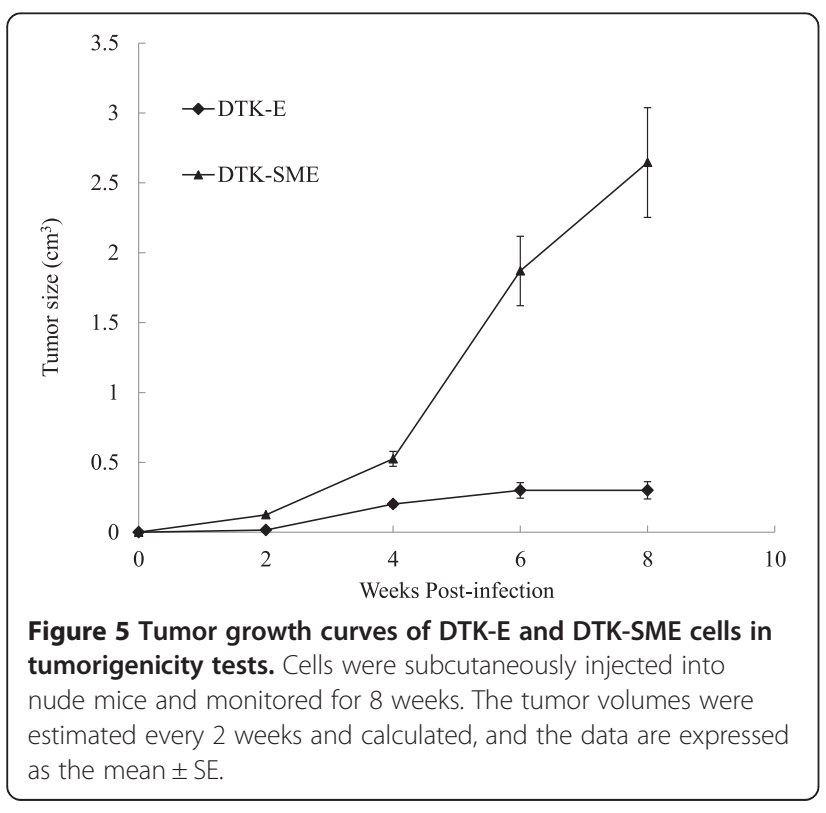

CK7 was associated with up to $96 \%$ of human breast epithelial neoplasms [24]. Other studies have also reported a high incidence of CK7 (56\%) in canine mammary gland carcinomas [25]. In this study, we showed that DTK-E and DTK-SME expressed CK7 and possessed high tumorigenicity. These results suggest that the DTK-E and DTK-SME cell lines could have originated directly from the tumor cells in the surgical specimen.

Vimentin is an intermediate filament protein expressed in mesenchymal cells [26]. Vimentin expression in invasive breast carcinomas is generally considered to indicate the epithelial-to-mesenchymal transition or myoepithelial histogenesis. Vimentin-positive breast tumors have been described as mostly malignant, highly invasive, and chemoresistant [27]. Interestingly, the DTK-E and DTK-SME cell lines established in this study were vimentin-positive and displayed tumorigenicity in mice.

HSP27 is a member of the small heat shock protein family of molecular chaperones. It plays an essential role in protein folding and protects cells from stress-induced damage $[28,29]$. In general, the healthy canine (and human) mammary gland exhibits little or no HSP27 expression [30-32]. In human breast cancer tumor cells, 

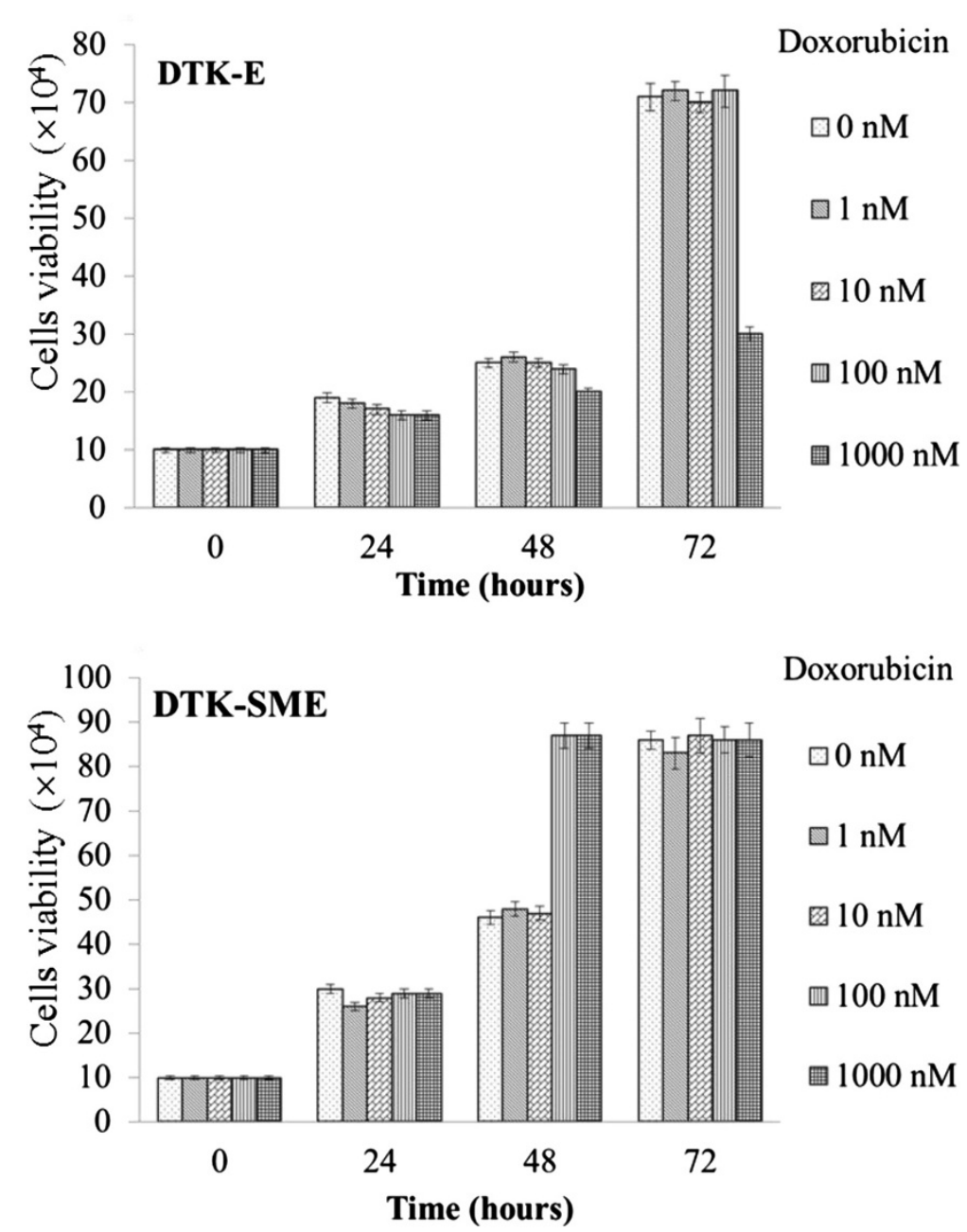

Figure 6 Effects of DOX on DTK-E and DTK-SME cell proliferation. Cells were treated with escalating doses of DOX (1, 10, 100, and 1000 nM) and incubated for $24 \mathrm{~h}, 48 \mathrm{~h}$, and $72 \mathrm{~h}$. Cell viability was determined every $24 \mathrm{~h}$. Cell numbers were averaged over triplicate samples, and the data are expressed as the mean \pm SE.

overexpression of HSP27 was associated with accelerated cancer progression [33], increased anchorage-independent growth [34], increased invasiveness [35,36], and resistance to chemotherapeutic drugs [34,37-39]. In patients, elevated expression of HSP27 in human breast cancer tissues has been shown to indicate poor prognosis and a low survival rate $[40,41]$. Therefore, increased expression of HSP27 in human breast cancers might affect the prognosis and treatment outcome [42].

DOX is an antitumor drug that can promote tumor cell apoptosis. Currently, DOX is widely used to treat a broad spectrum of cancers. In vitro studies of cancer cells have shown that HSP27 expression protects against apoptosis and confers resistance to DOX [38,43,44]. Interestingly, we also observed an association between increased HSP27 expression and resistance to DOX (Figures 6 and 7). Indeed, HSP27 expression was elevated in both the DTK-E and DTK-SME cell lines, although the expression level was higher in DTK-SME cells. Accordingly, DTK-SME cells were more resistant to DOX-mediated apoptosis and tumor masses were larger than those of DTK-E cells. The correlation between HSP27 and CMT malignancy currently remains unclear; thus, these two CMT cell lines with different tumorigenicities may serve as a valuable cell model for future studies of the roles of HSP27 in tumorigenicity and chemoresistance.

\section{Conclusion}

We established and characterized two new CMT cell lines with diverse tumorigenic properties. DTK-E cells were large, flat, and epithelial-like, while DTK-SME cells showed a rounded epithelial-like morphology and possessed pile up. Both DTK-E and DTK-SME cells were vimentin ${ }^{+} / \mathrm{AE} 1^{+} / \mathrm{CK} 7^{+} / \mathrm{HSP} 27^{+}$and tumorigenic in nude mice. These two cell lines also exhibited 


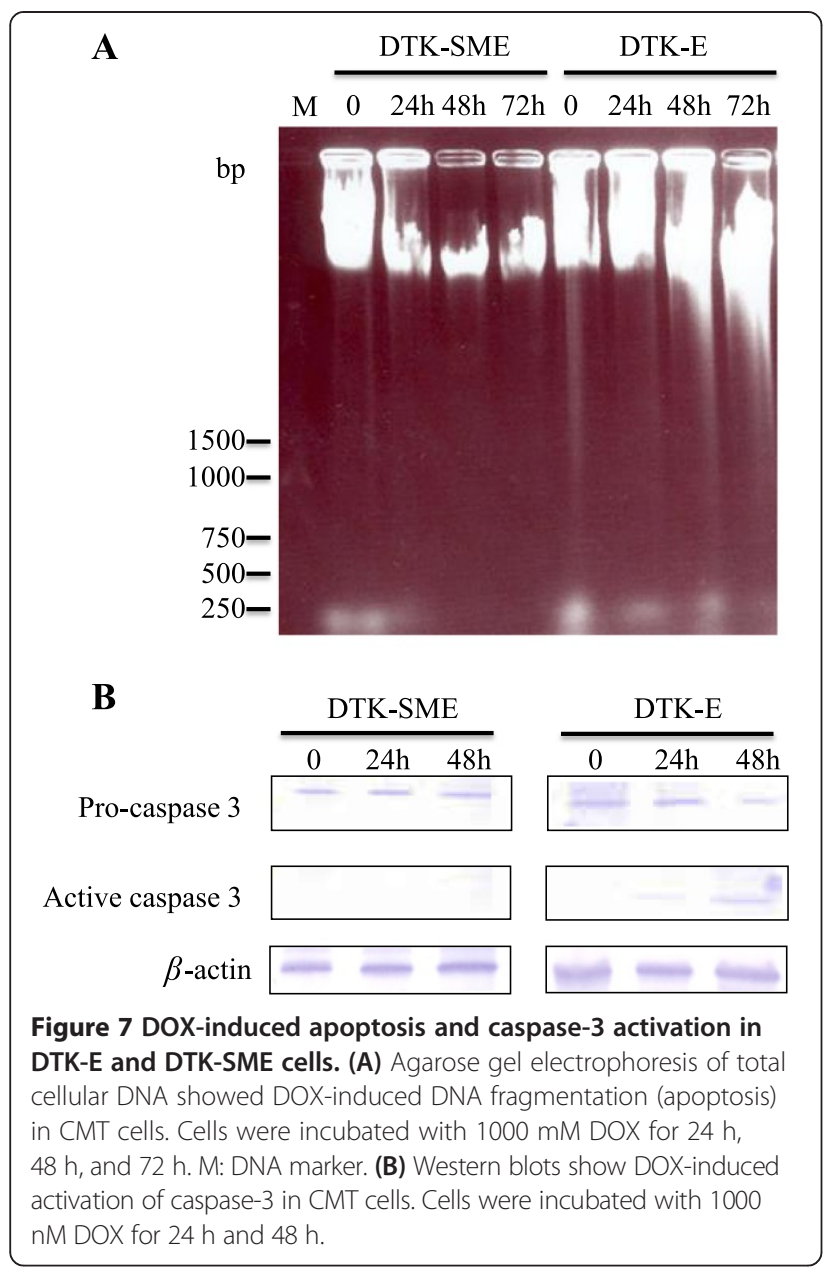

differential susceptibility to DOX-mediated apoptosis. Based on their diverse malignancy, tumorigenicity, protein marker profiles, and drug susceptibility, these newly established CMT cell lines represent useful cell models for basic tumor biology studies and for developing antitumor drugs to treat both human and canine breast carcinomas.

\section{Methods}

\section{Tumor specimen}

The tumor tissues used in this study were obtained from client-owned dogs with the consents of the owners acquired prior to sample collection. The handling of animals was practiced following a high standard of veterinary care. A tumor specimen was surgically excised from the mammary tissue of an 8-year-old mixed-breed female dog. Fresh neoplastic masses from the specimen were placed in primary culture, and the remaining samples were fixed in $10 \%$ formalin for histopathology. A histological examination confirmed the diagnosis of mammary carcinoma. Tumor specimens consisted of highly proliferating, luminal epithelial and fibroblastic stromal cells; they also had glandular structures with irregular lumens embedded in fibrous stroma.

\section{Establishment of cell lines}

A single tumor specimen was washed with RPMI 1640 medium (Sigma; St. Louis, MO, USA) that contained $500 \mathrm{IU} / \mathrm{mL}$ penicillin and streptomycin. The tissue was minced with scissors and transferred to a 60-mmdiameter tissue culture dish (Nunc; Waltham, MA USA) containing $10 \mathrm{~mL}$ of $0.25 \%$ trypsin solution $(0.25 \%$ trypsin and $0.2 \%$ ethylenediaminetetraacetic acid [EDTA] in phosphate-buffered saline [PBS]). The tissue suspension was gently agitated with a magnetic stir bar at $4^{\circ} \mathrm{C}$ for $1 \mathrm{~h}$. The resulting supernatant was transferred to a new tube. An equal volume of complete RPMI 1640 medium, containing 10\% FBS (Hyclone Laboratories; Logan, UT, USA) and $100 \mathrm{IU} / \mathrm{mL}$ penicillin and streptomycin was added and mixed well. The mixture was centrifuged at $180 \times g$ for $5 \mathrm{~min}$, and the pelleted cells were resuspended in fresh, complete medium. The cells were then seeded into $25-\mathrm{cm}^{2}$ culture flasks and incubated with complete medium at $37^{\circ} \mathrm{C}$ in a humidified atmosphere of 95\% air and 5\% $\mathrm{CO}_{2}$. Observations were performed daily with a phase-contrast microscope. When cultured cells reached $90 \%$ confluence, they were washed with $2 \mathrm{mM}$ EDTA in PBS, dispersed in the $0.25 \% \mathrm{w} / \mathrm{v}$ trypsin solution, and placed in a new flask at a density of $1 \times 10^{5}$ cells $/ \mathrm{mL}$. After 20 passages, cells were stored in RPMI 1640 medium containing 20\% FBS and 10\% dimethyl sulfoxide (Sigma). In addition, at passage 20, different cell types were subcloned from the parental cell line with a limiting-dilution method.

\section{Electron microscopy}

After 100 passages, cultured CMT cells were harvested, fixed with $2.5 \%$ glutaraldehyde in $0.1 \mathrm{M}$ cacodylate buffer, and placed at $4^{\circ} \mathrm{C}$ overnight. After fixation, the cells were treated with $1 \%$ osmium tetroxide at $4^{\circ} \mathrm{C}$ for $2 \mathrm{~h}$, washed in cacodylate buffer, dehydrated in graded acetone solutions, and embedded in Spur's low-viscosity resin. The embedded specimen was sectioned with a Reichert-Jung Ultracut E ultramicrotome (Nussloch, Germany), and the sections were stained with $2 \%$ uranyl acetate (EMS; Fort Washington, PA, USA) in distilled water for $1 \mathrm{~min}$. Images were acquired with a JEOL JEM 2000 EXII transmission electron microscope (JEOL Ltd.; Tokyo, Japan).

\section{Growth assay}

To investigate the growth of CMT cells, after 100 passages, $1 \times 10^{5}$ cells were seeded in $25-\mathrm{cm}^{2}$ tissue culture flasks and incubated in complete medium at $37^{\circ} \mathrm{C}$. After the cells were detached with trypsinization, they were stained with trypan blue in triplicate flasks and counted 
with a hemocytometer. The average number of cells was calculated and recorded.

\section{Western blot analysis}

CMT cells were collected and lysed with $100 \mu \mathrm{L}$ sample buffer that contained $100 \mathrm{mM}$ Tris- $\mathrm{HCl}$ buffer, $\mathrm{pH}$ 6.8, 4\% sodium dodecyl sulfate (SDS), $0.07 \% \quad \beta$-mercaptoethanol, $20 \%$ glycerol, and $0.2 \%$ bromophenol blue. The crude cell lysate proteins were electrophoresed on a 12\% SDSacrylamide gel and then stained with Coomassie Brilliant Blue R-250 for protein profiling or transferred to polyvinylidene fluoride membranes for western blot analysis. The membranes were blocked with $5 \%$ skim milk, incubated with primary antibodies (Table 1 ) for $2 \mathrm{~h}$, and subsequently incubated with alkaline phosphatase-conjugated secondary antibodies. Membranes were developed with 5-bromo-4chloro-3-indolyl phosphate and 4-nitro-blue tetrazolium chloride as substrates.

\section{Total RNA isolation and RT-PCR}

Total RNA was isolated from the cells using TRIzol reagent (Invitrogen; Paisley, Scotland, UK) according to the manufacturer's protocol. After digestion with RNasefree DNase (New England Biolabs; Beverly, MA, USA), $2 \mu \mathrm{g}$ of total RNA was reverse-transcribed into firststrand cDNA using random primers according to the Reverse Transcriptase Kit (Roche; Penzberg, Germany) protocol. The PCR was carried out in a volume of $50 \mu \mathrm{L}$ containing $2 \mu \mathrm{L}$ cDNA, $0.5 \mu \mathrm{M}$ forward primer, $0.5 \mu \mathrm{M}$ reverse primer, $2.5 \mu \mathrm{M}$ dNTP, $1 \times$ PCR buffer, and $2.5 \mathrm{U}$ Taq DNA polymerase (Viogene; Taipei, Taiwan). The primers for $C K 7$ were as follows: Forward-5' - CA GGTGCGCCTGAGCTCG-3', Reverse-5'-GCGGTAGG TGGCGATCTC-3'. PCR was carried out under the following conditions: $10 \mathrm{~min}$ at $95^{\circ} \mathrm{C} ; 35$ cycles of $1 \mathrm{~min}$ at $95^{\circ} \mathrm{C}, 1 \mathrm{~min}$ at $56^{\circ} \mathrm{C}$, and $1 \mathrm{~min}$ at $72^{\circ} \mathrm{C}$; and $10 \mathrm{~min}$ at $72^{\circ} \mathrm{C}$. The primers for HSP27 were as follows: Forward-5'ATGACCGAGCGCCGAGTGCCC-3', Reverse-5' -CTTG GCTCCAGACTGCTCCGA-3'. PCR was carried out under the following conditions: $5 \mathrm{~min}$ at $95^{\circ} \mathrm{C} ; 35$ cycles of $45 \mathrm{~s}$ at $95^{\circ} \mathrm{C}, 45 \mathrm{~s}$ at $54^{\circ} \mathrm{C}$, and $1 \mathrm{~min}$ at $72^{\circ} \mathrm{C}$; and $10 \mathrm{~min}$ at $72^{\circ} \mathrm{C}$. The primers for $\beta$-actin were as follows: Forward-5' -CTGGGACGACATGGAGAA-3', Reverse5'-GAGTACTTGCGCTCAGG-3'. PCR was carried out under the following conditions: $5 \mathrm{~min}$ at $95^{\circ} \mathrm{C}$; 35 cycles of $45 \mathrm{~s}$ at $95^{\circ} \mathrm{C}, 45 \mathrm{~s}$ at $55^{\circ} \mathrm{C}$, and $45 \mathrm{~s}$ at $72^{\circ} \mathrm{C}$; and $10 \mathrm{~min}$ at $72^{\circ} \mathrm{C}$. The PCR products were electrophoresed on a $1.2 \%$ agarose TAE-buffered gel and stained with ethidium bromide.

\section{Tumorigenicity}

Animal handling and experimental procedures were approved by the Institutional Animal Care and Use Committee of National Ilan University (Reference number: No. 103-10). After 100 passages, CMT cells $\left(1 \times 10^{7}\right)$ were subcutaneously inoculated into the backs of 8-week-old athymic BALB/c nude mice. Five nude mice were used to test each cell line. Physiological data of the mice were recorded weekly, and tumor volumes were estimated every 14 days and calculated as described previously [45]. Mice were sacrificed 56 days after inoculation. Results are expressed as the mean tumor volume.

\section{Susceptibility to doxorubicin}

After 100 passages, CMT cells $\left(1 \times 10^{5}\right)$ were seeded into $25-\mathrm{cm}^{2}$ tissue culture flasks in triplicate. After 24-h incubation, cells were treated with the antitumor drug DOX for $72 \mathrm{~h}$. Mock control cells were treated with water. After the treatment, cells were trypsinized, harvested, stained with $0.4 \%$ trypan blue, and counted with a hemocytometer under a light microscope. The average number of cells in triplicate flasks was calculated and recorded.

\section{DNA ladder assay}

After DOX (1000 nM) treatment, cells were collected and lysed at $55^{\circ} \mathrm{C}$ for $1 \mathrm{~h}$ in $500 \mu \mathrm{L}$ lysis buffer that contained $100 \mathrm{mM} \mathrm{NaCl}, 10 \mathrm{mM}$ Tris (pH 8.0), $25 \mathrm{mM}$ EDTA, $0.5 \%$ SDS, $200 \mu \mathrm{g} / \mathrm{mL}$ DNase-free proteinase K (Sigma), and $50 \mu \mathrm{g} / \mathrm{mL}$ DNase-free RNase (Sigma). DNA was extracted with phenol/chloroform, precipitated with $100 \%$ ethanol, and resuspended in double-distilled water. DNA samples were then separated on $1.6 \%$ agarose gels and stained with ethidium bromide.

\section{Abbreviations}

CMT: Canine mammary tumor; CK: Cytokeratin; CK7: Cytokeratin 7; HSP27: Heat shock protein 27; DOX: Doxorubicin; FBS: Fetal bovine serum; EDTA: Ethylenediaminetetraacetic acid; PBS: Phosphate-buffered saline; SDS: Sodium dodecyl sulfate.

\section{Competing interests}

The authors declare that they have no competing interests.

\section{Authors' contributions}

TZH, cell lines establishment, growth assay; CJL, western blot analysis; YLH and YHC, susceptibility to doxorubicin assay; CTL, tumor specimen and electron microscopy; CYC and YSL, establishment of cell lines, tumorigenicity and apoptosis assays, statistical analysis, manuscript and figure preparation. All authors read and approved the final manuscript.

\section{Authors' information}

TZH: Master degree student (Department and Graduate Institute of Veterinary Medicine, National Taiwan University, Taipei, Taiwan). CJL: Professor (Department of Nursing, Chang Gung University of Science and Technology, Taoyuan, Taiwan). YLH: Master degree student (Department of Biotechnology and Animal Science, National Ilan University, Yilan, Taiwan). YHC: Professor (Department of Biotechnology and Animal Science, National llan University, Yilan, Taiwan).

CTL: Professor (Department and Graduate Institute of Veterinary Medicine, National Taiwan University, Taipei, Taiwan).

CYC: Associate research fellow (Institute of Cellular and Organismic Biology, Academia Sinica, Taipei, Taiwan). 
YSL: Associate professor (Department of Biotechnology and Animal Science, National Ilan University, Yilan, Taiwan).

\section{Acknowledgements}

This study was supported by grant nos. NSC 91-2320-B-001-049-B and 94-2815-C-197-013-B from the National Science Council, Taiwan.

\section{Author details}

'Department of Biotechnology and Animal Science, National Ilan University, Yilan, Taiwan. ${ }^{2}$ Department and Graduate Institute of Veterinary Medicine, National Taiwan University, Taipei, Taiwan. ${ }^{3}$ Institute of Cellular and Organismic Biology, Academia Sinica, Taipei, Taiwan. ${ }^{4}$ Department of Nursing, Chang Gung University of Science and Technology, Taoyuan, Taiwan. ${ }^{5}$ Research Center for Industry of Human Ecology, Chang Gung University of Science and Technology, Taoyuan, Taiwan.

Received: 10 February 2014 Accepted: 22 September 2014 Published online: 30 September 2014

\section{References}

1. Jemal A, Bray F, Center MM, Ferlay J, Ward E, Forman D: Global cancer statistics. CA Cancer J Clin 2011, 61:69-90.

2. Misdorp W: Tumors of the Mammary Gland. In Tumors in Domestic Animals. 4th edition. Edited by Meuten DJ. Iowa, USA: Iowa State Press; 2002:575-606.

3. Brodey RS, Goldschmidt MH, Roszel JR: Canine mammary gland neoplasms. J Am Anim Hosp Assoc 1983, 19:61-90.

4. Martin PM, Cotard M, Mialot JP, Andre F, Raynaud JP: Animal models for hormone-dependent human breast cancer. Relationship between steroid receptor profiles in canine and feline mammary tumors and survival rate. Cancer Chemother Pharmacol 1984, 12:13-17.

5. Nieto A, Pena L, Perez-Alenza MD, Sanchez MA, Flores JM, Castano M: Immunohistologic detection of estrogen receptor alpha in canine mammary tumors: clinical and pathologic associations and prognostic significance. Vet Pathol 2000, 37:239-247.

6. MacEwen EG: Spontaneous tumors in dogs and cats: models for the study of cancer biology and treatment. Cancer Metastasis Rev 1990, 9:125-136.

7. Louzada S, Adega F, Chaves R: Defining the sister rat mammary tumor cell lines $\mathrm{HH}-16 \mathrm{cl} .2 / 1$ and $\mathrm{HH}-16 . \mathrm{cl} .4$ as an in vitro cell model for Erbb2. PLoS One 2012, 7:e29923.

8. Gazdar AF, Girard L, Lockwood WW, Lam WL, Minna JD: Lung cancer cell lines as tools for biomedical discovery and research. J Natl Cancer Inst 2010, 102:1310-1321.

9. Vargo-Gogola T, Rosen JM: Modelling breast cancer: one size does not fit all. Nat Rev Cancer 2007, 7:659-672

10. Chang CY, Chiou PP, Chen WJ, Li YH, Yiu JC, Cheng YH, Chen SD, Lin CT, Lai YS: Assessment of the tumorigenesis and drug susceptibility of three new canine mammary tumor cell lines. Res Vet Sci 2010, 88:285-293.

11. Nakatsu N, Yoshida Y, Yamazaki K, Nakamura T, Dan S, Fukui Y, Yamori T: Chemosensitivity profile of cancer cell lines and identification of genes determining chemosensitivity by an integrated bioinformatical approach using cDNA arrays. Mol Cancer Ther 2005, 4:399-412.

12. Ruhe JE, Streit $S$, Hart S, Wong CH, Specht K, Knyazev P, Knyazeva T, Tay LS, Loo HL, Foo P, Wong W, Pok S, Lim SJ, Ong H, Luo M, Ho HK, Peng K, Lee TC, Bezler M, Mann C, Gaertner S, Hoefler H, lacobelli S, Peter S, Tay A, Brenner S, Venkatesh B, Ullrich A: Genetic alterations in the tyrosine kinase transcriptome of human cancer cell lines. Cancer Res 2007, 67:11368-11376.

13. Pfragner R, Behmel A, Hoger H, Beham A, Ingolic E, Stelzer I, Svejda B, Moser VA, Obenauf AC, Siegl V, Haas O, Niederle B: Establishment and characterization of three novel cell lines - P-STS, L-STS, H-STS - derived from a human metastatic midgut carcinoid. Anticancer Res 2009, 29:1951-1961.

14. Shoemaker RH: The NCl60 human tumour cell line anticancer drug screen. Nat Rev Cancer 2006, 6:813-823.

15. Van Staveren WC, Solis DY, Hebrant A, Detours V, Dumont JE, Maenhaut C: Human cancer cell lines: experimental models for cancer cells in situ? For cancer stem cells? Biochim Biophys Acta 2009, 1795:92-103.

16. Kao J, Salari K, Bocanegra M, Choi YL, Girard L, Gandhi J, Kwei KA, Hernandez-Boussard T, Wang P, Gazdar AF, Minna JD, Pollack JR: Molecular profiling of breast cancer cell lines defines relevant tumor models and provides a resource for cancer gene discovery. PLoS One 2009, 4:e6146.
17. Gudjonsson T, Adriance MC, Sternlicht MD, Petersen OW, Bissell MJ: Myoepithelial cells: their origin and function in breast morphogenesis and neoplasia. J Mammary Gland Biol Neoplasia 2005, 10:261-272.

18. Ronnov-Jessen L, Petersen OW, Bissell MJ: Cellular changes involved in conversion of normal to malignant breast: importance of the stromal reaction. Physiol Rev 1996, 76:69-125.

19. Abd El-Rehim DM, Pinder SE, Paish CE, Bell J, Blamey RW, Robertson JF, Nicholson RI, Ellis IO: Expression of luminal and basal cytokeratins in human breast carcinoma. J Pathol 2004, 203:661-671.

20. Gupta RK, Naran S, Dowle C, Simpson JS: Coexpression of vimentin cytokeratin and S-100 in monomorphic adenoma of salivary gland; value of marker studies in the differential diagnosis of salivary gland tumours. Cytopathology 1992, 3:303-309.

21. Harbaum L, Pollheimer MJ, Kornprat $P$, Lindtner RA, Schlemmer A, Rehak $P$ Langner C: Keratin 7 expression in colorectal cancer-freak of nature or significant finding? Histopathology 2011, 59:225-234

22. Trask DK, Band V, Zajchowski DA, Yaswen P, Suh T, Sager R: Keratins as markers that distinguish normal and tumor-derived mammary epithelial cells. Proc Natl Acad Sci USA 1990, 87:2319-2323.

23. Henderson D, Weber K: Immuno-electron microscopical identification of the two types of intermediate filaments in established epithelial cells. Exp Cell Res 1981, 132:297-311.

24. Chu P, Wu E, Weiss LM: Cytokeratin 7 and cytokeratin 20 expression in epithelial neoplasms: a survey of 435 cases. Mod Pathol 2000, 13:962-972.

25. Espinosa de los Monteros A, Fernandez A, Millan MY, Rodriguez F, Herraez P, Martin de las Mulas J: Coordinate expression of cytokeratins 7 and 20 in feline and canine carcinomas. Vet Pathol 1999, 36:179-190.

26. Hellmen $E$, Lindgren $A$ : The expression of intermediate filaments in canine mammary glands and their tumors. Vet Pathol 1989, 26:420-428.

27. Korsching E, Packeisen J, Liedtke C, Hungermann D, Wulfing P, Van Diest PJ, Brandt B, Boecker W, Buerger $\mathrm{H}$ : The origin of vimentin expression in invasive breast cancer: epithelial-mesenchymal transition, myoepithelial histogenesis or histogenesis from progenitor cells with bilinear differentiation potential? J Pathol 2005, 206:451-457.

28. De Maio A: Heat shock proteins: facts, thoughts, and dreams. Shock 1999, $11: 1-12$

29. Morimoto RI, Kline MP, Bimston DN, Cotto JJ: The heat-shock response: regulation and function of heat-shock proteins and molecular chaperones. Essays Biochem 1997, 32:17-29.

30. Ciocca DR, Oesterreich S, Chamness GC, McGuire WL, Fuqua SA: Biological and clinical implications of heat shock protein 27,000 (Hsp27): a review. J Natl Cancer Inst 1993, 85:1558-1570.

31. Devaja O, King RJ, Papadopoulos A, Raju KS: Heat-shock protein 27 (HSP27) and its role in female reproductive organs. Eur J Gynaecol Oncol 1997, 18:16-22.

32. Romanucci M, Marinelli A, Sarli G, Della Salda L: Heat shock protein expression in canine malignant mammary tumours. BMC Cancer 2006, 6:171.

33. Love S, King RJ: A 27 kDa heat shock protein that has anomalous prognostic powers in early and advanced breast cancer. $\mathrm{Br} \mathrm{J}$ Cancer 1994, 69:743-748.

34. Oesterreich S, Weng CN, Qiu M, Hilsenbeck SG, Osborne CK, Fuqua SA: The small heat shock protein hsp27 is correlated with growth and drug resistance in human breast cancer cell lines. Cancer Res 1993, 53:4443-4448.

35. Lemieux P, Oesterreich S, Lawrence JA, Steeg PS, Hilsenbeck SG, Harvey JM, Fuqua SA: The small heat shock protein hsp27 increases invasiveness but decreases motility of breast cancer cells. Invasion Metastasis 1997, 17:113-123.

36. Grzegrzolka J, Kurnol K, Piotrow P, Pula B, Kobierzycki C, Piotrowska A, Jablonska K, Wojnar A, Rys J, Dziegiel P, Podhorska-Okolow M: Hsp-27 expression in invasive ductal breast carcinoma. Folia Histochem Cytobiol 2012, 50:527-533.

37. Diaz-Chavez J, Fonseca-Sanchez MA, Arechaga-Ocampo E, Flores-Perez A, Palacios-Rodriguez Y, Dominguez-Gomez G, Marchat LA, Fuentes-Mera L, Mendoza-Hernandez G, Gariglio P, López-Camarillo C: Proteomic profiling reveals that resveratrol inhibits HSP27 expression and sensitizes breast cancer cells to doxorubicin therapy. PLoS One 2013, 8:e64378.

38. Hansen RK, Parra I, Lemieux P, Oesterreich S, Hilsenbeck SG, Fuqua SA: Hsp27 overexpression inhibits doxorubicin-induced apoptosis in human breast cancer cells. Breast Cancer Res Treat 1999, 56:187-196.

39. Shi P, Wang MM, Jiang LY, Liu HT, Sun JZ: Paclitaxel-doxorubicin sequence is more effective in breast cancer cells with heat shock protein 27 overexpression. Chin Med J (Engl) 2008, 121:1975-1979. 
40. Ciocca DR, Calderwood SK: Heat shock proteins in cancer: diagnostic, prognostic, predictive, and treatment implications. Cell Stress Chaperones 2005, 10:86-103.

41. Thanner F, Sutterlin MW, Kapp M, Rieger L, Morr AK, Kristen P, Dietl J, Gassel AM, Muller T: Heat shock protein 27 is associated with decreased survival in node-negative breast cancer patients. Anticancer Res 2005, 25:1649-1653.

42. Wei L, Liu TT, Wang HH, Hong HM, Yu AL, Feng HP, Chang WW: Hsp27 participates in the maintenance of breast cancer stem cells through regulation of epithelial-mesenchymal transition and nuclear factor-kappaB. Breast Cancer Res 2011, 13:R101.

43. Di X, Shiu RP, Newsham IF, Gewirtz DA: Apoptosis, autophagy, accelerated senescence and reactive oxygen in the response of human breast tumor cells to adriamycin. Biochem Pharmacol 2009, 77:1139-1150.

44. Havasi A, Li Z, Wang Z, Martin JL, Botla V, Ruchalski K, Schwartz JH, Borkan SC: Hsp27 inhibits Bax activation and apoptosis via a phosphatidylinositol 3-kinase-dependent mechanism. J Biol Chem 2008, 283:12305-12313.

45. Noel A, De Pauw-Gillet MC, Purnell G, Nusgens B, Lapiere CM, Foidart JM: Enhancement of tumorigenicity of human breast adenocarcinoma cells in nude mice by matrigel and fibroblasts. Br J Cancer 1993, 68:909-915.

doi:10.1186/s12917-014-0229-0

Cite this article as: Hsiao et al:: Characterization of protein marker expression, tumorigenicity, and doxorubicin chemoresistance in two new canine mammary tumor cell lines. BMC Veterinary Research $201410: 229$

\section{Submit your next manuscript to BioMed Central and take full advantage of:}

- Convenient online submission

- Thorough peer review

- No space constraints or color figure charges

- Immediate publication on acceptance

- Inclusion in PubMed, CAS, Scopus and Google Scholar

- Research which is freely available for redistribution 